Collection: RegioResources21 - "Spatial information and participation of socio-ecological systems: experiences, tools and lessons learned for land-use planning"

Guest Editors: Daniele La Rosa, Carsten Lorz, Hannes Jochen König, Christine Fürst

\section{The feasibility of implementing cross-border land-use management strategies: a report from three Upper Silesian Euroregions}

\author{
Marcin Spyra
}

This paper presents several comments concerning land-use management strategies for three Czech-Polish Euroregions: Pradziad, Silesia and Cieszyn Silesia. These Euroregions comprise part of the Upper Silesia cross-border region. The study was conducted interviewing management representatives of each Euroregion on a set of questions concerning land-use strategies in the cross-border Czech-Polish Euroregions. The first section of the questionnaire concerned the need for such strategies, and the impediments to their implementation and their content. The second section described possible methods for implementing Euroregion land-use strategies after their preparation. It is argued that Euroregion land-use management strategies should reflect such aspects as the further development of the Euroregion as a cross-border institution and should include selected issues regarding economic development and the natural environment. The lack of enthusiasm among Euroregion members, the limitations of the 2014-2020 European Union budget and difficulties in achieving a single Czech-Polish development vision are the main obstacles in the implementation of the mentioned land-use strategies. Moreover, the importance of adequate Czech-Polish borderland planning tools and the role of citizens in Euroregion development are emphasised. The utility of a Euroregion scale for regional and national land-use management is discussed, using the example of the Upper Silesia cross-border region. The connection of the study results with regional land-use norms is explored, incorporating current strategic documents concerning the Czech-Polish borderland and existing legislation from both sides of the border. Some conclusions concerning appropriate crossborder landscapes land-use planning tools are outlined.

Keywords: Czech-Polish Borderland, Upper Silesia, Euroregion, Cross-border Land-use Management Strategy

\section{Introduction}

The Association of European Border Regions (AEBR) defines "Euroregion" as an organisational unit that allows and stimulates the cooperation of local governments and other public and private bodies on both sides of the border (AEBR 2000). As Perkmann \& Spicer (2007) noted, Euroregions are "organising templates for coordinating policies among contiguous local or regional authorities across national borders" (p. 12). Euroregions are dynamic constructs in which different processes are taking place, such as setting development goals, searching for new financing possibilities and expanding membership structures (Perkmann 2003).

In the context of this study, the land-use management strategy should be understood as a joint document regarding the CzechPolish borderland in the Euroregion area. It was assumed that the structure of such a do- cument should start with an evaluation (diagnosis) of the Euroregion's potential (location, land cover, infrastructure, demography, education, economy, analysis of existing strategic documents), followed by an analytical/strategic discussion (development scenarios, development and strategic goals, development priorities and implementation strategies are important, in that they should help to coordinate the development of the cross-border region (CBR), make transnational cooperation much smoother, and thus have a positive impact on cross-border ecosystems. On the other hand, land-use goals, interests concerning the CBRs (and Euroregions) and legislatures of the Czech Republic and Poland differ in many ways (Ministerstwo Budownictwa Rzeczypospolitej Polskiej 2006). Moreover, the administrative divisions are different on each side of the bortools). Cross-border land-use management $\square$ Opole University of Technology, Faculty of Civil Engineering, Department of Civil Engineering and Architecture, Ul. Katowicka 48, 45-061 Opole (Poland)

@ Marcin Spyra (spyra@onet.pl)

Received: Jan 20, 2014 - Accepted: Mar 05, 2014

Citation: Spyra M, 2014. The feasibility of implementing cross-border land-use management strategies: a report from three Upper Silesian Euroregions. iForest 7: 396402 [online 2014-05-19] URL: http: / /www. sisef.it/iforest/contents/?id=ifor1248-007

Communicated by: Raffaele Lafortezza

der. The cross-border land-use management strategy should strengthen the cross-border cooperation and coordinate the development of a particular CBR (Euroregion). The strategy should be one of the most important documents used in the implementation of the European Union Multiannual Financial Framework for the years 2014-2020, by facilitating the efficient use of the investment. However, little research has been carried out on the need for land-use management strategies and methods concerning such crossborder strategies in central Europe in general, and the Czech Republic/Poland in particular.

The method in this study is based on interviews conducted at the top level of management of the three studied Czech-Polish Euroregions: Pradziad, Silesia and Cieszyn Silesia. The objective of this study is to analyse the possibilities for implementing new Czech-Polish land-use management strategies in the analysed Euroregions. Additionally, this study is intended to deliver an overview of the method for developing landuse management strategies, which could be useful for each of those Euroregions.

The purposes of the study include:

- Increasing knowledge about the need for and content of cross-border land-use management strategies in relation to the three Upper Silesian Euroregions.

- Proposing a method suitable for preparing future cross-border land-use strategy documents that separately cover the three Upper Silesian Euroregions.

\section{Cross-border land-use management strategies}

\section{The study area}

The study area includes three Euroregions located inside the Upper Silesia CBR: Pradziad, Silesia and Cieszyn Silesia (from west to east). Such Euroregion members are Czech and Polish communities and districts. The three Euroregions differ in population, 
Tab. 1 - Area, population and population density in the Pradziad, Silesia and Cieszyn Silesia Euroregions as of December 2006. Source: "Euroregiony na granicach Polski" Statistical Office of Wroclaw, Poland.

\begin{tabular}{|c|c|c|c|c|}
\hline Euroregion & Subregion & $\begin{array}{l}\text { Area } \\
{\left[\mathbf{k m}^{2}\right]}\end{array}$ & Inhabitants & $\begin{array}{l}\text { Population density } \\
\text { [persons per } \mathbf{k m}^{2} \text { ] }\end{array}$ \\
\hline \multirow{3}{*}{ Pradziad } & $\mathrm{CZ}$ & 1878 & 131583 & 70.07 \\
\hline & PL & 4186 & 628238 & 150.08 \\
\hline & Total & 6064 & 759821 & 125.3 \\
\hline \multirow{3}{*}{ Silesia } & $\mathrm{CZ}$ & 1116 & 224919 & 201.54 \\
\hline & PL & 1453 & 288163 & 198.32 \\
\hline & Total & 2569 & 513082 & 199.72 \\
\hline \multirow{3}{*}{ Cieszyn Silesia } & $\mathrm{CZ}$ & 763 & 351606 & 460.82 \\
\hline & PL & 967 & 305129 & 315.54 \\
\hline & Total & 1730 & 656735 & 379.62 \\
\hline \multirow{3}{*}{ Overall } & $\mathrm{CZ}$ & 3757 & 708108 & 188.48 \\
\hline & PL & 6606 & 1221530 & 184.91 \\
\hline & Total & 10363 & 1929638 & 186.2 \\
\hline
\end{tabular}

area, land use and economy, among other aspects (see Tab. 1).

The Upper Silesia CBR, defined by its historical borders based on the study by Kordecki \& Smolorz (2011), currently covers most of the area of the Polish Slaskie and Opolskie Voivodeships and the Czech Moravskoslezský region at the level of NUTTS 2 (Fig. 1). Upper Silesia is located in central Europe at the axis of the Moravian Gate, which is formed by the depression between the Carpathian Mountains and the Sudetes (Fig. 1). Culturally and politically, the CBR was shaped by German, Czech, Slovak, Jewish and Polish influences.

\section{Previous experiences}

Paasi (2010) raises the question of whether a "region" actually exists or is merely an idea. He stresses that a region should also be seen as an end product of a research process. Such issues seem to be important also in the context of defining CBRs and delimiting their areas. Elaborating land-use management strategies should be understood as an important element of such a research process, helping to clarify the specificity of the CBR and the strength of the idea behind it.

Beginning in the late 1980s, Czech-Polish cross-border cooperation began to grow as a result of bottom-up initiatives. The 1980s also saw an intensification of the discussion of land-use issues concerning the Czech-Polish cross-border area (Kotkowska 2012). The first document concerning these issues, "Coordination document for Czech-Polish borderland", was prepared in 1991. The document was updated several times, with the currently binding version "Study of the spatial development of the Polish-Czech borderland" ("Studium zagospodarowania przestrzennego pogranicza polsko-czeskiego"), being announced in 2006. Several issues such as environmental protection, infrastructure development, tourism and the labor market were discussed between the neighboring countries (Ministerstwo Budownictwa Rzeczypospolitej Polskiej 2006).

As requested in the above-mentioned document, a Euroregion land-use management strategy can help identify local common ideas and priorities for land-use planning at the Czech-Polish borderland that would be applicable to the whole Upper Silesia. This strategy will help fulfill the goal of central European land-use planning, namely to facilitate the decentralization process - the shifting of power from central governments to the local level (Beunen \& Opdam 2011). Moreover, the strategies discussed therein can be helpful in achieving the strategic goals of Czech-Polish borderland development, including the enhancement of the external and internal cohesion of the PolishCzech borderland and the protection and restore of natural and cultural resources. Such goals could be achieved by adopting a proper land-use policy based on an in-depth knowledge about each Euroregion acquired during the preparation of the local land-use strategies. In addition, these efforts would be promoted by: (i) coordinating different landuse planning initiatives on both sides of the border; (ii) formulating common Czech-Po-

Fig. 1 - Location of Pradziad, Silesia and Cieszyn Silesia Euroregions inside the Upper Silesia CBR.

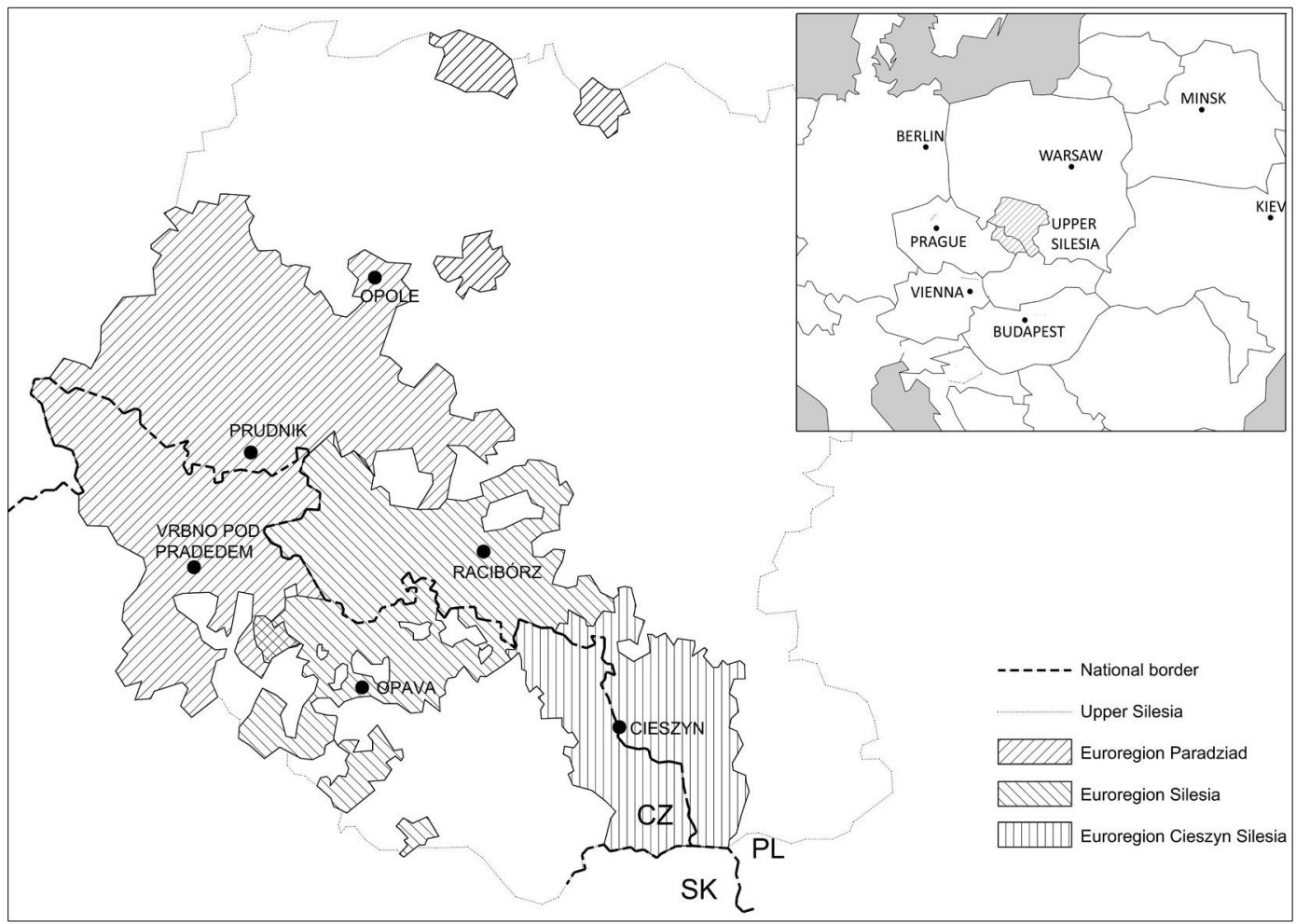


Tab. 2 - The project matrix (PM).

\begin{tabular}{|c|c|c|c|}
\hline \multicolumn{2}{|c|}{ Module Objective } & \multirow[b]{2}{*}{$\begin{array}{l}\text { Actions } \\
\text { (1) Research into the Euroregion's cross-border } \\
\text { landscape, with a focus on climate, microcli- } \\
\text { mate, geology, natural topography, water re- } \\
\text { sources, soil, fauna and flora, current land use, } \\
\text { infrastructure, demographic aspects, economy } \\
\text { history and culture. } \\
\text { (2) Consultations with public administration units } \\
\text { and the Euroregion, preceded by an analysis of } \\
\text { existing strategic documents. } \\
\text { (3) Public consultation (e.g., the Delphi method). } \\
\text { (4) Workshop for high-school students. } \\
\text { (5) Workshop for Polish and Czech students. }\end{array}$} & \multirow[b]{2}{*}{$\begin{array}{l}\text { Outcomes } \\
\text { Diagnosis of the Euroregion. User- } \\
\text { friendly and modifiable/updatable } \\
\text { interdisciplinary set of knowledge on } \\
\text { the Euroregion (its cross-border } \\
\text { landscape). }\end{array}$} \\
\hline M1 & $\begin{array}{l}\text { Collecting interdisciplinary know- } \\
\text { ledge about the Euroregion cross- } \\
\text { border landscape, which will be } \\
\text { used as a basis for the project } \\
\text { actions undertaken in later modules. }\end{array}$ & & \\
\hline M2 & $\begin{array}{l}\text { (1) Drawing up the } 2020 \text { Euroregion } \\
\text { development vision. } \\
\text { (2) Four versions of the } 2020 \\
\text { Euroregion development } \\
\text { scenarios based on the } \\
\text { outcomes of MODULE } 1 \text {. }\end{array}$ & $\begin{array}{l}\text { (1) Drawing up guidelines for the planning tools to } \\
\text { be developed in MODULE } 3 \text {. } \\
\text { (2) Public consultation on the development scena- } \\
\text { rios. } \\
\text { (3) Workshop for Polish and Czech students aimed } \\
\text { at commenting and developing the development } \\
\text { scenarios. } \\
\text { (4) Final version of the development scenarios. }\end{array}$ & $\begin{array}{l}\text { Guidelines for the planning tools to } \\
\text { be developed in MODULE } 3 \text {. }\end{array}$ \\
\hline M3 & $\begin{array}{l}\text { Setting priorities and strategic goals } \\
\text { for the Euroregion. Based on out- } \\
\text { comes of MODULE 2, developing } \\
\text { planning tools, namely, a set of } \\
\text { methods and actions to be used to } \\
\text { stimulate further development of } \\
\text { the Euroregion and further land-use } \\
\text { planning. }\end{array}$ & $\begin{array}{l}\text { (1) Formulating descriptive part of the strategy } \\
\text { (priorities, strategic goals, action lines, } \\
\text { planning tools). } \\
\text { (2) Organisation of a series of consultation work- } \\
\text { shops for representatives of the public and pri- } \\
\text { vate sector. } \\
\text { (3) Organisation of implementation workshops for } \\
\text { the Euroregion. } \\
\text { (4) Publications promoting project results. } \\
\text { (5) Establishment of an Expert Council to monitor } \\
\text { the development of the cross-border region } \\
\text { (similar to a think-tank). }\end{array}$ & $\begin{array}{l}\text { Euroregion land-use strategy, inclu- } \\
\text { ding a set of actions described in } \\
\text { detail (a toolbox), intended to stimu- } \\
\text { late further development of the } \\
\text { Euroregion. }\end{array}$ \\
\hline
\end{tabular}

lish strategic goals for the Euroregion; and (iii) ensuring the continuity of Czech and Polish strategic planning operations.

\section{Data collection}

The study was carried out between November 2012 and February 2013 through interviews to five Euroregions management representatives (presidents and directors of the Czech and Polish parts of each Euroregion). Euroregion executives were chosen to access the viewpoints of people responsible for the Euroregion's development.

Data were collected by a questionnaire composed of two sections (one and two). In section one, general issues about the Euroregion's current and future cross-border landuse planning initiatives were included, with the aim of:

- investigating the need of a cross-border land-use management strategy in the Upper Silesian Euroregions;

- assessing the main impediments to implementing these cross-border land-use management strategies; and

- analyzing the types of issues related to Euroregion planned development that should be addressed in cross-border land-use management strategies.
In section one, seven general open-ended and closed questions concerning the landuse strategies in the Czech-Polish Euroregions were formulated:

- 1A. What are the most important impediments to the Euroregion's development?

- 1B. If the Euroregion has a common Czech-Polish land-use strategy, which issues related to planned development were addressed in the strategy?

- 1C. If the Euroregion does not have a common Czech-Polish land-use strategy, which issues related to planned development should be addressed in such a document?

-1D. What are the main threats to implementing land-use strategies for cross-border regions?

-1E. Does the Euroregion have a common Czech-Polish land-use strategy (yes, no)?

- 1F. Are land-use strategies for cross-border regions necessary (definitely yes, yes, no, definitely no)?

- $1 \mathrm{G}$. Do land-use strategies for cross-border regions have a chance of being implemented (definitely yes, yes, no, definitely no)? In the section two of the questionnaire, the proposed land-use strategic planning method based on the project matrix (PM) was evaluated (Tab. 2). The PM represents a plan- ning scheme and is used as a theoretical basis to discuss and address the general challenges for implementing cross-border landuse management. The main aim of the PM is to structure the preparation of a land-use management strategy in a stepwise manner. The PM consists of three modules, M1, M2 and M3, described in detail in Tab. 2. The data concerning the Euroregion landscape collected in module M1 are sorted according to the method proposed by Steiner (2008), in which the main inventory elements are regional climate, earth, terrain, water, soil, microclimate, vegetation, wildlife and existing land use and land users. Moreover, information about the area's history, culture, economy and demography is included. Module M2 is based on the development of expert land-use scenarios for the Euroregions. Lastly, module M3 implements the results of the previous modules and formulates the strategic priorities and goals.

The purpose of this section was to:

- develop an outlook of the method to facilitate the future preparation of land-use management strategies for the three Upper Silesian Euroregions; and

- identify general challenges for land-use management in the studied area. 
The section two of the questionnaire consisted of 11 open-ended and closed questions:

- 2A. How would you rate the utility of actions described in the proposed PM (insufficient, sufficient, good, very good)?

- 2B. How would you rate the logic of the modules (M1, M2, M3) proposed in the PM (insufficient, sufficient, good, very good)?

- 2C. How would you rate the idea of using a foresight method to analyze the development potential of the Euroregion (insufficient, sufficient, good, very good)?

- 2D. How would you rate the potential help given by middle-school pupils in collecting interdisciplinary data about the Euroregion and different stories about the $\mathrm{Eu}$ roregion ("storytelling": insufficient, sufficient, good, very good)?

- 2E. How would you rate the possible help given by university students of the Opolskie, Slaskie and Moravsko-Slezkie "voivodeships" (administrative division) in collecting interdisciplinary knowledge about the Euroregion (storytelling about the Euroregion) and in creating development scenarios (insufficient, sufficient, good, very good)?

- $2 \mathrm{~F}$. How would you rate the citizens' involvement in the Euroregion development (insufficient, sufficient, good, very good)?

- 2G. How would you rate the existing brand of the Euroregion (insufficient, sufficient, good, very good)?

- $2 \mathrm{H}$. How would you rate the role of creative class members in the development of towns, cities and regions (entirely irrelevant, unimportant, important, very impor$\operatorname{tant}$ )?

- 2I. How would you rate the need for citizen involvement in the Euroregion's development (entirely irrelevant, unimportant, important, very important)?

- 2J. What are the necessary actions that should be implemented to increase citizens' involvement in the Euroregion's development?

- 2K. Which general aspects should be used to address the scenarios prepared in module 2?

\section{Interpretation of the results}

The answers to the questions from both sections of the questionnaire are presented in Tab. 3.

Results from section one clearly demonstrate that now is an appropriate time to examine the possibilities of implementing crossborder land-use strategies in the Euroregions analyzed. Only the Cieszyn Silesia Euroregion representative indicated that his/her institution has implemented cross-border strategic documents, namely "BORDER CROSSING - Model study of border crossings in the year 2005" and "INTERTURISM - Joint strategy for tourism development in the Silesian Beskid and Moravian-Silesian Beskid areas" (question 1E). At the time of the study the Polish association forming the Pradziad Euroregion was preparing a document entitled: "Strategy for Polish-Czech cooperation in the Pradziad Euroregion area in the years 2014-2020". The representatives acknowledged that cross-border land-use management strategies are very necessary (question $1 \mathrm{~F}$ ), and all interviewees indicated that implementing such documents should be possible (question 1G).

According to the results, issues that the cross-border land-use strategies should address can be classified into three general categories:

1. Further development of the Euroregion as a cross-border institution. The following issues were identified: strengthening crossborder cooperation between Euroregion stakeholders; identifying the issues affecting stakeholders' development and searching for ways to solve them; seeking financing sources (question 1C).

2. Economic development. The important aspects highlighted were: cross-border transport infrastructure; cross-border institutional cooperation (for instance, in the framework of cross-border clusters); the labor market; tourism and education (question $1 \mathrm{~B}$ and $1 \mathrm{C})$.

3 . The natural environment. The aspects deemed to be important in this area were: environmental hazards; environmental protection and preservation; liquidation of the consequences of natural disasters; inhabitants' quality of live (question 1B and 1C). Three main obstacles to the implementation of a cross-border land-use management strategy were identified (questions $1 \mathrm{~A}$ and 1D):

1. A lack of enthusiasm for or serious engagement with cross-border land-use planning among the Euroregion partners. This fact, combined with a fear of the European Union's procedures, a lack of new institutional members in the Euroregions, and the resignation of existing members, should be identified as the foremost threat to crossborder land-use planning. It indicates a need for the improvement of the Euroregion's brand and the building of trust among its members.

2. The uncertainty of the European Union's financial programming and budget for the years 2014-2020 was indicated as an impediment to cross-border land-use planning six times. This fact clearly indicates that both the process of land-use planning and further integration inside the Euroregions must be supported by proper financing.

3. It is difficult to achieve a common vision of land-use planning on both sides of the border. The representative of the Polish association in the Pradziad Euroregion indi- cated that it is difficult even to summon the will to work on such a document. The Polish association in Cieszyn Silesia Euroregion also stressed the importance of "proper cooperation with the Czech partner".

In section two the logic behind the proposed PM is appreciated, giving rise to the possibility of further elaboration and practical implementation of this theoretical planning scheme (questions 2A and 2B). Further considerations from the PM emphasize the following issues.

\section{Constant development of adequate land- use strategic management tools for the Czech-Polish borderland}

Results showed a marked potential for this area (question 2C). Moreover, the importance of involving different stakeholders in the early stage of the planning process was stressed by the interviewed Euroregion representatives (questions 2D \& 2E). Such involvement can be implemented by planning and providing workshops for stakeholders. Cooperating with the public administration during the planning process is considered a priority, while the involvement of middleschool pupils and university students is commonly less considered. Representatives of middle-school pupils and university students could be considered a "support squad" in the planning process, providing a different perspective (different stories) about the spatial problems of the Euroregions. These support squads should be engaged in the planned workshops: (i) by gathering data and compiling fundamental information and knowledge about the Euroregion's problems (PM, module M1); (ii) by critical reviewing and visualizing the land-use scenarios prepared (PM, module M2 - question $2 \mathrm{~K}$ ).

\section{Engagement of Czech and Polish citizens in the Euroregion's development}

From the perspective of the Euroregion management, citizens could be more involved in the Euroregion development (question 2F). Three out of five interviewed managers rate this factor as important, and the other two as very important (question 2I). Moreover, all interviewees recognize the important role of the creative class in the regional development (question $2 \mathrm{H}$ ). The answers to question $2 \mathrm{~J}$ suggest several possible approaches to this purpose, all based on frequent discussions among Czech and Polish stakeholders. A possibility is to improve the Euroregion's branding, which would encourage citizens to participate in Euroregion development in general and land-use in particular. The respondents' answers suggest that it is important to continuously develop and improve such a brand (question 2G). Again, planning workshops are also a promising tool for increasing citizen participation. 
Tab. 3 - Summary of all answers given in both sections of the study interviews.

\begin{tabular}{|c|c|c|c|c|}
\hline Section & Pradziad PL & Pradziad CZ & Silesia PL & Silesia CZ \\
\hline $1 \mathrm{~A}$ & - & $\begin{array}{l}\text { (1) The lack of a clear } \\
\text { target for bilateral coop- } \\
\text { eration }\end{array}$ & $\begin{array}{l}\text { (1) The lack of funds for conti- } \\
\text { nuing Euroregion activity } \\
\text { (2) Determination of "priority } \\
\text { themes" for European Union pro- } \\
\text { gramme period } 2014-2020 \text { in the } \\
\text { framework of the European Terri- } \\
\text { torial Cooperation, which does } \\
\text { not correspond to real Euroregion } \\
\text { needs } \\
\text { (3) Different opinions between } \\
\text { Polish and Czech partners about } \\
\text { development goals }\end{array}$ & $\begin{array}{l}\text { (1) No proper engagement of Eu- } \\
\text { roregion members in its activities } \\
\text { (2) Fear of European Union proce- } \\
\text { dures } \\
\text { (3) Lack of new members in Eu- } \\
\text { roregions and resignation of ex- } \\
\text { isting ones } \\
\text { (4) Financial problems (e.g., low } \\
\text { membership fees, microproject } \\
\text { administration) } \\
\text { (5) Little interest in new Czech- } \\
\text { Polish cooperation programme for } \\
\text { the years 2014-2020 } \\
\text { (6) Increasing disproportion be- } \\
\text { tween the Czech and Polish sides of } \\
\text { the Euroregion - better cooperation } \\
\text { promotion on the Polish side }\end{array}$ \\
\hline
\end{tabular}

\section{Cieszyn Silesia CZ / PL}

(1) Availability of funds from the European Union roregion members in its act framework of the European Terri- roregions and resignation of extorial Cooperation, which does needs

Different opinions between Polish and Czech partners about development goals

promotion on the Polish side

(1) Exchange of information and experiences concerning regional development, labor market

(2) Cooperation in the following fields: spatial planning, prevention and liquidation of consequences of natural disasters, rescue services, economy and trade, schools and young people, tourism and further improvement of crossborder traffic

(3) Solving common problems in the following fields: transport, communication, citizens security, ecology and environment protection

(4) Cultural exchange and concern for common cultural heritage

\begin{tabular}{|c|c|c|c|c|c|}
\hline $1 \mathrm{C}$ & $\begin{array}{l}\text { (1) Transport in- } \\
\text { frastructure } \\
\text { (2) Tourism } \\
\text { (3) Environmen- } \\
\text { tal hazards and } \\
\text { environmental } \\
\text { protection } \\
\text { (4) Education } \\
\text { (5) Labor market } \\
\text { (6) Social secu- } \\
\text { rity } \\
\text { (7) Health care } \\
\text { (8) Institutional } \\
\text { cooperation } \\
\text { (9) Economy }\end{array}$ & $\begin{array}{l}\text { (1) Continuing cross- } \\
\text { border cooperation of } \\
\text { municipalities and } \\
\text { other stakeholders } \\
\text { (2) Building lasting } \\
\text { friendships } \\
\text { (3) Defining new deve- } \\
\text { lopment goals }\end{array}$ & $\begin{array}{l}\text { (1) Institutional development of } \\
\text { the Euroregion } \\
\text { (2) Development of the Eurore- } \\
\text { gion as a strong association, } \\
\text { grouping its member communi- } \\
\text { ties and helping to solve their } \\
\text { problems } \\
\text { (3) Socio-economic development } \\
\text { (4) Increasing competitiveness } \\
\text { (5) Inhabitants' quality of life }\end{array}$ & $\begin{array}{l}\text { (1) Development of the Euroregion } \\
\text { as an institution able to raise its } \\
\text { own funds for its activities } \\
\text { (2) Continuous search for new fi- } \\
\text { nancing sources } \\
\text { (3) Involvement in projects and ac- } \\
\text { tivities that are interesting and ac- } \\
\text { ceptable to all Euroregion members } \\
\text { (4) Widening cooperation in the } \\
\text { framework of the Euroregion be- } \\
\text { yond its management down to each } \\
\text { member }\end{array}$ & \\
\hline 1D & $\begin{array}{l}\text { Lack of the Czech } \\
\text { partners' willing- } \\
\text { ness to cooperate }\end{array}$ & $\begin{array}{l}\text { "No strategy is currently } \\
\text { implemented" }\end{array}$ & $\begin{array}{l}\text { Similar to answers for question 1A } \\
\text { and } \\
\text { (1) No funds available for imple- } \\
\text { menting the strategy } \\
\text { (2) Organisational changes inside } \\
\text { the Euroregion }\end{array}$ & Same answers as for question $1 \mathrm{~A}$ & $\begin{array}{l}\text { Fluent cooperation between } \\
\text { Polish and Czech partners } \\
\text { comprising the Euroregion }\end{array}$ \\
\hline $1 \mathrm{E}$ & No & No & No & No & Yes \\
\hline $1 \mathrm{~F}$ & Definitely yes & Definitely yes & Definitely yes & Definitely yes & Yes \\
\hline $1 \mathrm{G}$ & Yes & Yes & Definitely yes & Yes & Yes \\
\hline $2 \mathrm{~A}$ & Very good & Very good & Sufficient & Good & Good \\
\hline $2 \mathrm{~B}$ & Very good & Good & Good & Sufficient & Good \\
\hline $2 \mathrm{C}$ & 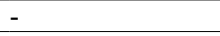 & Very good & Good & Good & Good \\
\hline $2 \mathrm{D}$ & Very good & Very good & Sufficient & Very good & Good \\
\hline $2 \mathrm{E}$ & Very good & Sufficient & Good & Very good & Very good \\
\hline $2 \mathrm{~F}$ & Insufficient & Very good & Sufficient & Sufficient & Sufficient \\
\hline $2 \mathrm{G}$ & Sufficient & Very good & Good & Good & Good \\
\hline
\end{tabular}


Tab. 3 (continued) - Summary of all answers given in both sections of the study interviews.

\begin{tabular}{|c|c|c|c|c|c|}
\hline Section & Pradziad PL & Pradziad CZ & Silesia PL & Silesia CZ & Cieszyn Silesia CZ / PL \\
\hline $2 \mathrm{H}$ & Very important & Important & - & Important & Important \\
\hline $2 \mathrm{I}$ & Important & Very important & Important & Very important & Important \\
\hline $2 \mathrm{~J}$ & $\begin{array}{l}\text { (1) Education in } \\
\text { Polish and Czech } \\
\text { schools } \\
\text { (2) Informational } \\
\text { meetings in diffe- } \\
\text { rent communities }\end{array}$ & $\begin{array}{l}\text { (1) Frequent and well- } \\
\text { prepared information } \\
\text { about bilateral coope- } \\
\text { ration and its impact } \\
\text { on quality of life } \\
\text { (2) Public discussion } \\
\text { of examples of other } \\
\text { similar "good prac- } \\
\text { tices" }\end{array}$ & Public debate & $\begin{array}{l}\text { (1) Raising awareness of the Eu- } \\
\text { roregion (further cross-border co- } \\
\text { operation, development of areas } \\
\text { close to the border, communica- } \\
\text { tion between people from both } \\
\text { sides of the border) } \\
\text { (2) Public discussion of examples } \\
\text { of other similar "good practices" } \\
\text { from other Czech, Polish and Eu- } \\
\text { ropean Euroregions }\end{array}$ & $\begin{array}{l}\text { (1) Awareness of the regio- } \\
\text { nal potential } \\
\text { (2) Deepening of citizens' } \\
\text { knowledge about the Eu- } \\
\text { roregion }\end{array}$ \\
\hline $2 \mathrm{~K}$ & $\begin{array}{l}\text { (1) Infrastructure } \\
\text { (2) Tourism } \\
\text { (3) Education } \\
\text { (4) Labor market } \\
\text { (5) Health care }\end{array}$ & No answer & $\begin{array}{l}\text { (1) Development of the Eurore- } \\
\text { gion as a strong association, } \\
\text { grouping its member communi- } \\
\text { ties } \\
\text { (2) Development of the Eurore- } \\
\text { gion as an institution } \\
\text { (3) Transport infrastructure } \\
\text { (4) Tourism, culture, sport } \\
\text { (5) Supporting entrepreneurship } \\
\text { (6) Development of human re- } \\
\text { sources Euroregion management }\end{array}$ & $\begin{array}{l}\text { (1) Development of the Eurore- } \\
\text { gion as an institution } \\
\text { (2) Transport infrastructure } \\
\text { (3) Culture } \\
\text { (4) Sport Economy/business } \\
\text { (5) Human resources } \\
\text { (6) Euroregion management } \\
\text { Specifying certain actions and } \\
\text { projects in selected strategic divi- } \\
\text { sions }\end{array}$ & $\begin{array}{l}\text { (1) Natural environment } \\
\text { (2) Waste management } \\
\text { (3) Health care } \\
\text { (4) Public security and } \\
\text { emergency management } \\
\text { (5) Economic development } \\
\text { of the Euroregion area }\end{array}$ \\
\hline
\end{tabular}

\section{Conclusions}

\section{Planning the CBR future}

There are few important needs for land-use management in Upper Silesia CBR at the Euroregion scale. A document on the crossborder land-use management strategy does not exist in either Polish or Czech planning legislation. However, the conclusions from the Euroregion land-use management strategy should be included in national planning procedures. First, these conclusions can serve as valuable framework for land-use management at the regional level on both sides of the border and as a basis for the regular updating of national documents, being prepared with the help of local citizens and public sector representatives. Second, selected issues elaborated in the Euroregion land-use management strategy should be included in detailed land-use plans concerning Czech and Polish communities or parts thereof. During the preparation of the Euroregion land-use management strategy, Czech and Polish communities should have the chance to express their opinions about each other's land-use plans. The process described above should be supported by the hierarchical nature of land-use planning that is well-established in the legislation, where planning at the community level takes into account the frameworks described in regional-level documents (Jedraszko 2005). Obviously, the differences in the land-use management/ planning legislation on each side of the border does not facilitate this implementation, but the proposed transnational and transparent process for preparing a Euroregion landuse management strategy (including adequate tools) can help overcome these difficulties.
The involvement of the Czech and Polish communities in the preparation of the requested land-use management strategy, identified as a critical issue, may help these public bodies to consider land-use management and planning form a wider, cross-border perspective, discouraging the unproductive "not in my backyard" line of thought. The involvement of Czech and Polish communities in cross-border land-use strategic management is significant in that these institutions are taking a substantial responsibility for the details of land-use planning in their areas.

Following are the issues identified in this study that can be linked to national/regional land-use norms/instruments.

\section{Increasing Polish and Czech stakeholders'} collaboration in the land-use planning process

The European Landscape Convention emphasizes the role of participation in landscape strategic planning, the need to raise awareness of the landscape and the role of training and education (Council of Europe 2000). Representatives of the public sector should obviously be involved in the planning process at the earliest stage (Whittington 1996). Different methods of transdisciplinary and participative land-use strategic planning have recently been discussed (e.g., Cantiani 2012, Cumming \& Norwood 2012, Sevenant \& Antrop 2010) and criticized (e.g., Stenseke 2009). Moreover, this study suggests the involvement of middle-school pupils and university students in the process via planning workshops. Those can serve as "support squads" for the overall process and can help in the identification of the planning problems, approaching from a different perspective (Spyra 2013).

\section{Use of foresight for land-use strategic} planning at the borderland

It is proposed to extend the foresight to the so-called "foresight 2.0 ", in which more emphasis is placed on leadership rather than on management over the whole planning process. The process itself is also more flexible and focuses not only on problem-solving but also goal-creation (Nelson 2010, Stevenson 2006). The literature has indicated a significant growth in interest in scenario planning (Varum \& Melo 2010). Scenario planning approaches based on qualitative imaginary and storytelling should be introduced as a possible instrument of cross-border land-use planning (MacKay \& McKiernan 2010, Ratcliffe \& Krawczyk 2011). Storytelling, which has been growing in importance over the last two decades, is an interesting and feasible approach (e.g., van Hulst 2012). The planner's role is to listen carefully to people's stories and, using proper tools and methods, systematize the knowledge therein and use it as a basis for the decision-making process.

\section{Future directions and research needs}

As discussed by Lepik (2009), Euroregions need to constantly define new development goals, cooperate with new types of members (e.g., NGOs, universities) and, above all, be aware of their financial resources. Better stakeholder involvement in land-use management could stimulate progress towards these goals. The Euroregion land-use management strategy can be used to overcome the impediments to Euroregion development mentioned in the interviews (Tab. 3). Specifically, it can be used to: (i) define clear targets for bilateral cooperation; (ii) prepare the Euroregion for the new European Union pro- 
gramme period (2014-2020); (iii) encourage the entrance of new members (e.g., districts and communities as well as NGOs and universities) into the Euroregion; and (iv) provide a more prominent role in national policies and participation in regional and national decision-making regarding land-use by serving as a reference for the Euroregion lobbying policy at the central governmental level on both sides of the border. In this way, the Euroregion land-use management strategy can help strengthen cross-border cooperation within all the Upper Silesia CBR in particular and other CBRs in general. All these issues should be considered as directions for future research.

Thackara (2006, p.43) writes that "dialogue and encounter are inescapable basis of trust in our relationships". He describes the creation of trust through time as the nemawashi ("laying the groundwork") factor. Trust must also be built between Czech and Polish stakeholders working on the cross-border landuse management strategy and planning the future of the CBR. Adequate land-use management tools and engagement of Czech and Polish citizens in the Euroregion's development, argued in this paper, should be an element of the nemawashi factor. This factor could be the motto for further research concerning cross-border land-use management in CBRs.

\section{Acknowledgments}

This research was partly supported by a scholarship from the Polish Ministry of Science and Higher Education for outstanding young scientists.

I would like to thank the Euroregions representatives for their kind help in collecting research material, especially Mr Piotr Bak from the Pradziad Euroregion. I would also like to thank my colleagues Piotr Obracaj and Zbigniew Zebaty from the Opole University of Technology, Daniele La Rosa from University of Catania, Luis Inostroza from Dresden University of Technology and Jan Bondaruk from the Central Mining Institute in Katowice. The research described in this study would not have been possible without our discussions and their helpful cooperation.

Moreover, I would like to thank anonymous reviewers for their valuable comments on an earlier version of this manuscript.

\section{References}

AEBR (2000). Practical guide to cross-border cooperation $\left(3^{\text {rd }}\right.$ edn). Association of European
Border Regions - AEBR, European Commission, Gronau, Germany, pp. 405. [online] URL: http:// www.aebr.eu/files/publications/lace_guide.en.pd $\mathrm{f}$

Beunen R, Opdam P (2011). When landscape planning becomes landscape governance, what happens to the science? Landscape and Urban Planning 100: 324-326. - doi: 10.1016/j.landurbplan.2011.01.018

Cantiani M (2012). Forest planning and public participation: a possible methodological approach. iForest 5: 72-82. - doi: 10.3832/ifor0602 $-009$

Cumming G, Norwood C (2012). The community voice method: using participatory research and filmmaking to foster dialog about changing landscapes. Landscape and Urban Planning 105: 434-444. - doi: 10.1016/j.landurbplan.2012.01. 018

Council of Europe (2000). European landscape convention. Council of Europe Treaty Series no. 176, Florence, Italy, pp. 4. [online] URL: http:// www.coe.int/t/dg4/cultureheritage/heritage/Land scape/default en.asp

Jedraszko A (2005). Zagospodarowanie przestrzenne w Polsce - drogi i bezdroza regulacji ustawowych [Spatial planning in Poland - roads and off-roads of statutory regulations]. Unia Metropolii Polskich, Warsaw, Poland, pp. 245307.

Kordecki M, Smolorz D (2011). Górny slask = Oberschlesien. Dom Wspólpracy Polsko-Niemieckiej, Gliwice, Poland.

Kotkowska A (2012). Polsko-Czeskie pogranicze. Bariery we wspólpracy i sposoby ich przelamywania. Wspólne planowanie przestrzenne i strategiczne [Polish - Czech borderland. Barriers to cooperation and ways of overcoming them. Bilateral land-use planning]. In: Proceedings of the conference "Infrastruktura transportowa oraz planowanie strategiczne i przestrzenne w relacjach Polsko-Czeskich [Transport infrastructure and strategic and spatial planning in PolishCzech relations]". Wroclaw (Poland) 5 Oct 2012, pp. 5. [in Polish] [online] URL: http://www.osw.waw.pl/sites/default/files/wydarzenia/zaprosze nie-wroclaw-cz 0.pdf

Lepik KL (2009). Euroregions as mechanisms for strengthening cross-border cooperation in the Baltic Sea Region. Trames 13: 265-284. - doi: 10.3176/tr.2009.3.05

MacKay B, McKiernan P (2010). Creativity and dysfunction in strategic processes: the case of scenario planning. Futures 42: 271-281. - doi: 10.1016/j.futures.2009.11.013

Ministerstwo Budownictwa Rzeczypospolitej Polskiej (2006). Studium zagospodarowania przestrzennego pogranicza polsko-czeskiego [Land-use study of Polish-Czech borderland]. Ministerstwo
Budownictwa Rzeczypospolitej Polskiej, Departament Ladu Przestrzennego i Architektury, Wroclaw, Poland and Ministerstvo pro Místní Rozvoj Ceské Republiky, Odbor Územních Vazeb, Prague, Czech Republic. [in Polish]

Nelson R (2010). Extending foresight: the case for and nature of Foresight 2.0. Futures 42: 282-294. - doi: 10.1016/j.futures.2009.11.014

Paasi A (2010). Regions are social constructs, but who or what "constructs" them? Agency in question. Environment and Planning A 42: 22962301. - doi: 10.1068/a42232

Perkmann M (2003). Cross-border regions in $\mathrm{Eu}-$ rope. European Urban and Regional Studies 10: 153-171. - doi: 10.1177/0969776403010002004

Perkmann M, Spicer A (2007). "Healing the scars of history": projects, skills and field strategies in institutional entrepreneurship. Organization Studies 28: 1101-1122. - doi: 10.1177/017084060 7078116

Ratcliffe J, Krawczyk E (2011). Imagineering city futures: the use of prospective through scenarios in urban planning. Futures 43: 642-653. - doi: 10.1016/j.futures.2011.05.005

Sevenant M, Antrop M (2010). Transdisciplinary landscape planning: does the public have aspirations? Experiences from a case study in Ghent (Flanders, Belgium). Land Use Policy 27: 373386. - doi: 10.1016/j.landusepol.2009.05.005

Spyra M (2013). Economic Development Opportunities for the Pradziad Euroregion Borderland. In: "Cross-border landscape of Euroregion Pradziad" (Spyra M eds). Oficyna Wydawnicza Politechniki Opolskiej, Opole, Poland, pp. 84-91.

Steiner F (2008). The living landscape. an ecological approach to landscape planning. Island Press, Washington, USA, pp. 8.

Stenseke M (2009). Local participation in cultural landscape maintenance: lessons from Sweden. Land Use Policy 26: 214-223. - doi: 10.1016/j.landusepol.2008.01.005

Stevenson T (2006). From vision into action. $\mathrm{Fu}-$ tures 38: 667-672. - doi: 10.1016/j.futures.2005. 10.009

Thackara J (2006). In the bubble: designing in the complex world. MIT Press, Cambridge, USA, pp. 43.

Whittington R (1996). Strategy as practice. Long Range Planning 29: 731-735. - doi: 10.1016/002 4-z6301(96)00068-4

van Hulst M (2012). Storytelling, a model of and a model for planning. Planning Theory 11: 299318. - doi: 10.1177/1473095212440425

Varum CA, Melo C (2010). Directions in scenario planning literature - a review of the past decades. Futures 42: 355-369. - doi: 10.1016/j.futures. 2009.11.021 